\title{
Czetö Krisztina
}

ELTE Pedagógiai és Pszichológiai Kar Neveléstudományi Intézet

\section{Az iskolához való viszony fogalmi értelmezéseinek összehasonlító vizsgálata: iskolai attitüd, jóllét és elköteleződés}

Jelen elméleti kutatás a tanulók iskolához kapcsolódó kognitív, affektív és viselkedéses viszonyulásait, azok mintázatait, valamint az iskolai mindennapokbban való részvételük minóségét megragadó konstruktumok összehasonlitó-elemzó vizsgálatával foglalkozik. Az iskolai attitúdöt az iskolához való érzelmi-társas közelség érzésén keresztül megragadó konstruktumok (school connectedness/belonging/bond) a társas kapcsolatok minóségét, az azokba való bevonódás és ráforditás mértékét, valamint a társaktól és tanároktól megtapasztalt elfogadás, támogatás érzését állitják a középpontba (vö. Lohmeier és Lee, 2012; Goodenow és Grady, 1993; Jenkins, 1997). Az elkötelezódés/bevonódás (engagement) mint meta-konstruktum pedig a tanulók affektiv, kognitiv és viselkedéses mintázatait jelöli, és itt is megfigyelhetó egyfajta tartalmi diverzitás az összetevók számát és tartalmát illetően a különbözó megközelítésekben (vö. Fredricks és mtsai, 2004; Appleton és mtsai, 2008; Griffiths és mtsai, 2009; Reschly és Christenson, 2012). Az elkötelezódés/bevonódás több komponensú modelljei komplex képet adhatnak a tanulók iskolához fúzódó kapcsolatáról és annak dimenzióiról.

\section{Bevezetés}

A modernitástól kezdődően - a gyermekkor intézményesülésével párhuzamosan létrejöttek a gyermekkorhoz kapcsolódó társadalmi intézmények (vö. Gillis, 2009; Zeiher, 2009), és a kötelező iskolarendszerek megjelenésével a gyermeki tevékenység jelentős részét már az iskolában töltött idő tette ki (vö. Szabolcs, 201; Czető, 2018). Az iskolarendszerek a gyermekek státuszát is fomálták: a 'gyermekből' egyben 'tanuló' is lett (vö. Szabolcs, 2011). Mindez azt is magával hozta, hogy a kötelező oktatás a gyermekeket „elzárta” más társadalmi terektől, és kialakultak azok a gyermekkorhoz köthető normatív, a felnőtt nézőpontból hasznos tevékenységekre irányuló társadalmi elvárások, melyek megteremtették az 'iskolázott gyermek' konstrukcióját (vö. Hendrick, 1997; Zeiher, 2009; Szabolcs, 2011; Czetö, 2018). Ugyanakkor az iskoláztatás nem kizárólag kötelezettséggé, hanem - az oktatáshoz való hozzáférés (müvelődés) joga által - alapvető emberi és 
gyermeki joggá is alakult (Freeman, 1998, 2000, 2009; Lansdown, 2003; Lundy, 2005; Monk, 2009; Kjørholt, 2008; Quennerstedt, 2011; Tisdall és Punch, 2012).

A tudásalapú társadalmakban a tudástőke felértékelődése (Gazsó és Laki, 2004; Csapó, $2002 \mathrm{a} ; 2002 \mathrm{~b}$ ) a tanulókat a gazdasági versenyképesség szempontjából is értékessé teszi (vö. Czető, 2018). Napjaink későmodern/ posztmodern társadalmi, gazdasági és kulturális változásai kikezdik a modernitás során kialakult iskola intézményét, és alakítják az iskola gyermekkor-észlelését is (vö. Nagy és Trencsényi, 2012; Czető, 2018). Zinnecker (2001) szerint a gyermek- és ifjúkor egy olyan periódussá vált, mely lehetővé tesz egyfajta „legitim” távolmaradást bizonyos társadalmi normáktól és kötelezettségektől (vö. kulturális moratórium) (Zinnecker, 2001; Golnhofer és Szabolcs, 2005; Szabolcs, 2011; Czető, 2018). Az oktatás tömegessé válásával a gyermekkor és az ifjúkor a személyiségfejlődés, a kognitív tanulás, a kulturális javak megszerzésének időszakává vált és felértékelődött, mellyel a gyermekkor a kulturális aktivitás, fogyasztás időszaka lett. Zinnecker (2001) szerint a gyermekek fogyasztóvá váltak az iskola (a tanulás) világában is, és alakítják, önálló értelmezésekkel, jelentéssel látják el környezetüket (vö. Corsaro, 2015; James, 2013). A gyermeki tevékenységek és a generációs kapcsolatok változásai (vö. Qvortrup, 2009; Zinnecker, 2011; Nagy és Trencsényi, 2012) egyre inkább azt jelzik, szükségessé válik az iskola társadalmi szerepének és funkcióinak újragondolása. A gyermekkor új szociológiai megközelítése ráirányította a figyelmet a gyermekek aktív és jelentésteremtő társadalmi szerepére, és a gyermekek és fiatalok „hangjának”, a társadalmi világról alkotott értelmezéseinek megismerése felértékelődött a társadalomtudományi kutatásokban. A gyermekkor megváltozásával az iskola egyre nagyobb kihívással nézhet szembe, hogy hogyan tud hiteles és vonzó társadalmi teret biztosítani a gyermekek és fiatalok számára (vö. Nagy és Trencsényi, 2012; Czetö, 2018). Az iskola szerepének és feladatainak (újra)értelmezése során meghatározó jelentőségű a tanulók iskolához való viszonyulásának megértése.

\section{A tudásalapú társadalmakban}

a tudástóke felértékelódése

(Gazsó és Laki, 2004; Csapó, 2002a; 2002b) a tanulókat a

gazdasági versenyképesség szempontjából is értékessé teszi

(vö. Czetó, 2018). Napjaink késómodern/posztmodern társadalmi, gazdasági és kulturális változásai kikezdik a modernitás során kialakult iskola intézményét, és alakitják az iskola gyermekkor-észlelését is (vö. Nagy és Trencsényi, 2012; Czetó, 2018). Zinnecker (2001) szerint a gyermek-és ifjúkor egy olyan periódussá vált, mely lehetôvé tesz egyfajta „legitim” távolmaradást bizonyos társadalmi normáktól és kötelezettségektól

(vö. kulturális moratórium) (Zinnecker, 2001; Golnhofer és Szabolcs, 2005; Szabolcs, 2011; Czetô, 2018). Az oktatás tömegessé válásával a gyermekkor és az ifjúkor a személyiségfejlódés, a kognitív tanulás, a kulturális javak megszerzésének idöszakává vált és felértékelódött, melylyel a gyermekkor a kulturális aktivitás, fogyasztás idôszaka lett. Zinnecker (2001) szerint a gyermekek fogyasztóvá váltak az iskola (a tanulás) világában is, és alakitják, önálló értelmezésekkel, jelentéssel látják el környezetüket (vö. Corsaro, 2015; James, 2013). 
Mindezekhez szorosan kapcsolódva, jelen tanulmány egy elméleti kutatás eredményeit összegzi, melynek célja az iskolai attitüd (mint ernyőfogalom) alá sorolható - elsősorban a nemzetközi szakirodalomban feltárható - konstruktumok elméleti-összehasonlító vizsgálata. Az elméleti kutatás eredményei koncepcionálisan megalapozták és előkészítették egy iskolai attitüd kérdőív kialakítását, majd ez alapján egy empirikus vizsgálat megvalósítását. A tanulmány szeretne továbbá hozzájárulni a tanulók iskoláról alkotott értelmezéseinek mélyebb megértéséhez is.

\section{Az iskolához viszonyulás feltárása: az iskolai attitüd konstrukciói}

\section{A megelözö kutatások eredményei}

A tanulók iskolához kapcsolódó nézeteinek, attitűdjeinek feltárása - a gyermekkor mélyebb megértése mellett - az iskola iránti kedvező viszonyulás kialakításának is alapja, mely hosszú távon a tanulók tanulási minőségére, jóllétére is hatással van.

A kapcsolódó empirikus kutatások (vö. Jenkins és mtsai, 1997; Stern, 2012) megerősítették, hogy a kedvező iskola iránti orientáció esetén a tanulók énhatékonyság-érzése is kedvezően alakult: a tanulók az iskola szeretetéről számoltak be, jellemzően elfogadták és tisztelték az iskola szabályait, és úgy vélték, az akadémiai teljesítmény, a tanulás releváns az életükben. Gottfredson (2010) kutatása azt is feltárta, hogy az iskolához való kötődés alakulásában döntő jelentőségü a tanár-diák interakció (Gottfredson, 2010; Stern, 2012). A tanulók pontosan észlelik, hogy a tanárok milyen előfeltevéseket alakítanak ki a bennük rejlő potenciálokról, miképpen értékelik erőfeszítéseiket, majd igazodnak ezekhez az elvárásokhoz. A rendszeresen túlterhelt, szorongó, a tanulmányi elvárásoknak megfelelni nem tudó tanulók negatív érzésekről számoltak be az iskolához kapcsolódóan (Gottfredson, 2010; Stern, 2012).

A tematikusan kapcsolódó hazai nézetkutatások a tanulók iskolaértelmezéseit (vö. Golnhofer és Szabolcs, 2005; Hunyady és M. Nádasi, 2014;), valamint az iskolához társított érzelmeket vizsgálták (vö. Rapos, 2003; Réthy, 2009). Ezek a kutatások feltárták, hogy a tanulók észlelésében a 'tanuló' szerep sokszor elhalványítja a személyiség egyéb sajátosságait (Golnhofer és Szabolcs, 2005); az iskola gyakran negatív viszonyulásokat vált ki, ezáltal a kényszer érzését kelti (vö. Réthy, 2009), míg az iskolai teljesítményhez misztikus, túlértékelt értelmezések kapcsolódnak (vö. Rapos, 2009), melyek beépülnek a tanulók önértékeléseibe is (vö. Mészáros és mtsai, 1997).

A 'naiv' nézeteket feltáró vizsgálatok mellett a hazai iskolaiattitűd-kutatások elsősorban az iskolai kötődés (Szabó és Virányi, 2011; Szabó, Zsadányi és Szabó-Hangya, 2015), az iskolai attitüd (Czető, 2018) és a tantárgyi attitüdök (Csapó, 2000) vizsgálatára fókuszáltak. A kötődésvizsgálatok feltárták, hogy a kedvező iskolai kötődés a tanulók iskolai énképére is pozitív hatással van, valamint csökkenti a tanulói streszsz-szintjét, továbbá kedvezően alakítja az énhatékonyság megélését, illetve a tanulói motivációt is (Szabó és Virányi, 2011; Szabó, Zsadányi és Szabó-Hangya, 2015). Szintén fontos eredmény, hogy az iskolai attitüd és az iskolai teljesítmény egymás elörejelzői lehetnek (Czető, 2018). A tantárgyi attitüdre vonatkozó kutatásában Csapó (2000) a tantárgyi érdeklődés differenciálódását, illetve a tanulmányi teljesítménnyel való összefüggéseit vizsgálta. Kutatása alapján megerősödött, hogy egy tantárgy tanulási ideje befolyásolja a tantárgyi attitüd alakulását, azaz minél hosszabb ideig tanulnak egy tárgyat, annál kevésbé számolnak be pozitív attitüdről a tanulók, illetve, hogy a középiskola legelső éveiben írható le a legerösebb összefüggés a tantárgyak és az osztályzatok között, és szintén van összefüggés az általános attitüd és a tárgyi attitüdök között (Csapó, 2000). 
Nem találkozunk azonban olyan hazai elméleti kutatásokkal, melyek az iskolához való viszony fogalmi megragadhatóságával, az azt leíró konstruktumok koncepcionális elemzésével foglalkoznának. Jelen kutatás a narratív irodalmi feltárás módszerét alkalmazva ezt a hiányt törekszik pótolni.

\section{Fogalmi sokszínüség és elméleti megközelitések}

A fogalmi megközelítéseket vizsgáló nemzetközi szakirodalmakban (vö. például Libbey, 2004; Stern, 2012) különböző, sok esetben egymást átfedő fogalmakkal és megközelítésekkel találkozhatunk a tanulók iskolához kapcsolódó viszonyulásainak, az iskolai életben való részvételük minőségének megragadására. Az iskolához való viszonyt - az iskolai attitüd fogalmát - különböző elméleti konstrukciókkal írják le, azonban a koncepcionális tisztázatlanság, a fogalmi átfedések megnehezítik a jelenség kutatását is. A fogalmak tartalmi diverzitása mellett további nehézséget jelent azok szerteágazó ${ }^{1}$ megnevezése is (vö. Libbey, 2004; Stern, 2012), ami a fogalmi-tartalmi lényeget megragadó, az értelmezések közötti finom különbségeket érzékeltető fordításokat is nehézségek elé állítják. Libbey (2004) szerint sokszor az azonos kifejezések használata esetén sem beszélhetünk egységes értelmezésekről, még az azonos fogalmak jelentése is attól függ, ki használja éppen a fogalmat.

Tanulmányomban a tanulók iskolához kapcsolódó kognitív, affektív és viselkedéses viszonyulásait, azok mintázatait, valamint az iskolai mindennapokban való részvételük minőségét megragadó konstruktumokat - Stern (2012) fogalomhasználatát követve - az 'iskolai attitüd' (school attitude) mint ernyőfogalom alá rendezem. Stern (2012) szerint az iskolai attitüd az iskola iránt mutatott pozitív vagy negatív viszonyulásokat átfogó, az egyén szubjektív jóllétét leíró fogalom. Az attitűd értelmezéseinek áttekintése túlmutat jelen tanulmány terjedelmi keretein (erröl ld. pl. Czető, 2018). Az attitüdök értelmezésében alapvetőnek tekintem, hogy azok három komponens komplex összekapcsolódása mentén alakuló, viselkedésben, érzelmekben és vélekedésekben megnyilvánuló, az egyén ítéleteit összegző mentális reprezentációk (vö. Smith, Mackie és Claypool, 2004; Fiske, 2006). Az attitűdök eltérő válaszokat alakítanak ki: az affektív korrelátumok az attitüdtárgy iránti érzelmeket/érzéseket, a kognitív korrelátumok a kapcsolódó tényeket, nézeteket/vélekedéseket szervezik, míg a viselkedéses korrelátumok a lezajló interakciókra (elkerülés/megközelítés) vonatkozó cselekvési beállítódások (Fiske, 2006; Smith, Mackie és Claypool, 2004). Mindezek alapján - értelmezésemben - az attitüd kellően tág és komplex lehet a fogalmi sokszínüség rendszerezésére. McCoach (2003) értelmezésében az iskolai attitüd az iskolához (valamint az ahhoz társított egyéb tényezőkhöz) kapcsolódó pozitív vagy negatív érzelmek intenzitása, vagyis az iskolai attitüd azoknak a pozitív vagy negatív hatásoknak az összessége, melyek az iskola mellett (vagy éppen ellenében) formálódnak, és magukban hordozzák az iskolához, a tanuláshoz és a tanárokhoz kötődő érzelmeket is.

A fogalmi sokszínüség alapját Stern (2012) szerint az adja, hogy az egyes megközelítések az érzelmi viszonyulások, illetve az iskolai életbe való bevonódás mely területeire fókuszálnak. Libbey (2004) az iskolai attitűd alá tartozó fogalmak értelmezéseit rendszerező tanulmányában szintén kitér a fogalom megragadhatóságának nehézségére. A széles fogalmi spektrum szerinte nemcsak a jelenség kutatását állítja kihívások elé, de az iskolai attitüd konstrukcióinak pontos (gyakorlati) alkalmazását is megnehezíti. A fogalmi tisztázás jelentősége - ahogyan arra Libbey (2004) is utal - így tehát nem egy kizárólagos

1 Jelen elméleti kutatás keretében elsősorban angol nyelven vizsgált. 
fogalom használatának támogatása lehet, hanem a fogalom mögött meghúzódó tartalmi különbségek tisztázása, a jövőbeni kutatások elősegítése.

Az iskolához való viszony, az iskolai életről alkotott tanulói percepciók megragadására - ahogyan a korábbiakban is utaltam rá - a nemzetközi szakirodalomban sokféle fogalmi megnevezéssel találkozhatunk. Ezek rövid áttekintését (jelen tanulmány keretei között a teljesség igénye nélkül) az 1. táblázat mutatja. A school connectedness (vö. Libbey, 2004; Stern, 2012; Lohmeier és Lee, 2012); a school belonging (vö. Goodenow és Grady, 1993), a school bond (vö. Jenkins, 1997), az engagement (vö. Fredricks és mtsai, 2004; Appleton és mtsai, 2008; Griffiths és mtsai, 2009; Alrashidi és mtsai, 2016), illetve a school well-being (vö. Konu és Rimpela, 2002) és a school satisfaction (vö. Baker és Maupin, 2009) mind az iskolához kapcsolódó tanulói percepciók és attitüdök különböző aspektusait felölelö, az iskolai élet minőségét a tanulók szempontjából közelítő fogalmak. Az egyes fogalmak számos tartalmi dimenzió mentén mutatnak egyezést, azonban eltérő elméleti megközelítésekre épülnek, és az iskolai élet eltérő területeit emelik ki összetevőkként.

A hazai kutatásokban, mint az előzőekben felsorolt fogalmakhoz tartalmában és jelentésében legközelebb álló konstruktum, az iskolai kötődés fogalmával találkozhatunk (vö. Szabó és Virányi, 2011; Szabó, Zsadányi és Szabó-Hangya, 2015). Kutatásukban Szabó és Virányi (2011) is utal rá, hogy az iskolai kötődés fogalmának értelmezése sem egységes. Megközelítésükben elsősorban a fogalom érzelmi aspektusait emelik ki, és azt három összetevő mentén írják le: az iskolai társas kapcsolatok természete, az iskolai tevékenységek és a fizikai környezet kiváltotta érzetek. Az iskolához való viszony kialakulásában úgy vélik, hogy a kezdeti, formálódó attitűdökből egy magasabb érzelmi kapcsolat alakulhat ki, melyet kötődésként írnak le.

Az affektív kapcsolódások természetének megértése kiemelt jelentőségü az iskolához való viszony vizsgálatában (vö. Libbey, 2004; Stern, 2012). Szintén fontos látnunk, hogy az iskolai attitüdhöz kapcsolt fogalmak elnevezése és összetevői valóban az iskolához tartozás megélésének különböző aspektusait, az érzelmi-társas közelség minőségeit is megjelenítik. Látnunk kell azonban azt is, hogy a kötődés (mint egy erős érzelmi involváltságot feltételező állapot) megragadhatósága az előzőekben vázolt dimenziók mentén számos kihívást rejthet magába. Az iskolai attitüd konstrukciók széttartó természetüek, az iskolai élet különböző területire fókuszálnak, így fontos lehet az elnevezések mögött meghúzódó összetevők és értelmezések vizsgálata is. 


\begin{tabular}{|c|c|c|}
\hline \multicolumn{3}{|c|}{ 1. táblázat. Az iskolai attitüd ernyöje alá sorolt fogalmak rövid áttekintése (saját szerkesztés) } \\
\hline Fogalom & Szerző & Elméleti koncepció \\
\hline $\begin{array}{l}\text { school } \\
\text { connectedness }\end{array}$ & Libbey (2004) & A tanulók iskolához füződő kapcsolata (átfogóan). \\
\hline $\begin{array}{c}\text { school } \\
\text { connectedness }\end{array}$ & $\begin{array}{l}\text { Lohmeier \& Lee } \\
\qquad(2012)\end{array}$ & $\begin{array}{l}\text { Az iskolához tartozás érzését leíró, a társas kapcsola- } \\
\text { tok minőségét megragadó fogalom. } \\
\text { Az összetartozás (kötődés) (connectedness) elméleti } \\
\text { megközelítésén alapul, mely alapján a konstruktum } \\
\text { három további szintjei: } \\
\text { 1) Általános támogatottság (a valahova tartozás } \\
\text { megélése). } \\
\text { 2) Specifikus támogatottság (szorosabb kötődések } \\
\text { megélésé). } \\
\text { 3) Elköteleződés/bevonódás. }\end{array}$ \\
\hline $\begin{array}{l}\text { school } \\
\text { belonging }\end{array}$ & $\begin{array}{l}\text { Goodenow \& Grady } \\
\text { (1993) }\end{array}$ & $\begin{array}{l}\text { Az iskolához tartozás érzésének tanulói percepciója: a } \\
\text { tanulók mennyire érzik magukat az iskola tagjának (el- } \\
\text { fogadottság, támogatottság, megbecsülés és tisztelet). }\end{array}$ \\
\hline school bond & Jenkins (1997) & $\begin{array}{l}\text { Az iskolához való érzelmi kapcsolat, valamint az } \\
\text { iskolai tevékenységekbe való bevonódás leírása. }\end{array}$ \\
\hline $\begin{array}{c}\text { school } \\
\text { attachment }\end{array}$ & $\begin{array}{l}\text { Moody \& Bearman } \\
\qquad(1998)\end{array}$ & $\begin{array}{l}\text { Érzelmi és szociális közelség átélése az iskolában } \\
\text { (ennek összetevői: az iskolában töltött idő minősége, } \\
\text { az iskolai közösséghez tartozás megtapasztalása). }\end{array}$ \\
\hline engagement & $\begin{array}{l}\text { Fredricks (2004); } \\
\text { Appleton és mtsai } \\
\text { (2008); Griffiths és } \\
\text { mtsai (2009) }\end{array}$ & $\begin{array}{l}\text { A tanulók eltérő motivációs, affektív, kognitív és } \\
\text { viselkedéses mintázatait megragadó fogalom: az is- } \\
\text { kolai élet különböző területein a tanulók érzelmei- } \\
\text { nek, nézeteinek és tevékenységeinek sajátosságai. }\end{array}$ \\
\hline engagement & $\begin{array}{l}\text { Schaufeli és mtsai } \\
\qquad(2001)\end{array}$ & $\begin{array}{l}\text { A tanuló számára kielégítő, pozitív, a különböző } \\
\text { tanulási tevékenységhez kapcsolódó - hosszabban } \\
\text { fennálló - kognitív-affektív állapot. }\end{array}$ \\
\hline $\begin{array}{c}\text { school } \\
\text { satisfaction }\end{array}$ & $\begin{array}{l}\text { Baker \& Maupin } \\
\text { (2009) }\end{array}$ & $\begin{array}{l}\text { A tanulók szubjektív ítélete az iskolai élet minősé- } \\
\text { géről. }\end{array}$ \\
\hline $\begin{array}{l}\text { school } \\
\text { well-being }\end{array}$ & $\begin{array}{l}\text { Konu \& Rimpela } \\
\qquad(2002)\end{array}$ & $\begin{array}{l}\text { Az iskolai élet minőségét és az iskolai feltételeket } \\
\text { és sajátosságokat leíró konstruktum, Allardt (1989) } \\
\text { 'having-loving-being' jóllét modelljét adaptálja az } \\
\text { iskolai környezetekre. }\end{array}$ \\
\hline
\end{tabular}

Libbey (2004) a tanulók iskolához füződő kapcsolatának (átfogó) leírására a school connectedness fogalmat vezeti be, és annak elsősorban érzelmi és viselkedéses aspektusait emeli ki (vö. Stern, 2012). Elméleti kutatásában a fogalmak tartalmi, rendszerező elemzését végezte el. Egyrészt vizsgálta az eltérő fogalomhasználat mögött meghúzódó elméleti megközelítéseket, feltárta azok tartalmi egyezését más fogalmakkal; másrészt elemezte az egyes konstruktumok mellé társított mérőeszközök tartalmi sajátosságait. Kutatása rávilágított a különböző elnevezéssel használt fogalmak koncepcionális átfedéseire, ezzel is jelezve a következetes fogalmi megközelítések hiányát. Elemzésének további fontos eredménye lehet, hogy az általa használt school connectedness fogalomhoz kapcsolódóan kilenc olyan összetevőt azonosított, melyek az egyes megközelítésekben következetesen megjelenő tartalmi elemek voltak. Ezek a következők: 1. akadémiai 
elköteleződés; 2. az iskolához tartozás érzése; 3. tanulói percepciók az iskolai fegyelemről és igazságosságról; 4. extrakurrikuláris tevékenységek; 5. az iskola szeretete; 6. a tanulók hangja; 7. kortárs kapcsolatok; 8. biztonság és 9. tanári támogatás.

Az egyes változók tartalmi értelmezését Libbey (2004) és Stern (2012) alapján a 2. táblázat összegzi.

2. táblázat. Az iskolához füzödö kapcsolatot leiró fogalmak (school connectedness) közös változói és azok tartalma (Libbey, 2004 és Stern, 2012 alapján, saját szerkesztés)

\begin{tabular}{|c|c|}
\hline Összetevők & Tartalma \\
\hline 1. Akadémiai elköteleződés: & $\begin{array}{l}\text { Annak megragadása, hogy a tanuló milyen mértékben motivált } \\
\text { a tanulásra és arra, hogy jól teljesítsen az iskolában. }\end{array}$ \\
\hline $\begin{array}{l}\text { 2. Az iskolához tartozás } \\
\text { érzése: }\end{array}$ & $\begin{array}{l}\text { Annak kifejezése, hogy a tanuló mennyire érzi magát az isko- } \\
\text { lai közösség tagjának. Ez megnyilvánulhat olyan pozitív érzel- } \\
\text { mekben, mint: } \\
\text { a) a tanuló büszke iskolájára; } \\
\text { b) úgy érzi, megbecsült (értékes) tagja a közösségnek; } \\
\text { c) pozitív kapcsolata van kortársaival és tanáraival, és } \\
\text { d) lehetősége van az önkifejezésre. }\end{array}$ \\
\hline $\begin{array}{l}\text { 3. Tanulói percepciók az } \\
\text { iskolai fegyelemről és } \\
\text { igazságosságról: }\end{array}$ & $\begin{array}{l}\text { Az iskolai szabályok tanulói észleléseinek sajátosságaira } \\
\text { vonatkozó elemek. A tanulók szubjektív észlelései az egyen- } \\
\text { lőség, igazságosság iskolai megvalósulásáról és a szabályok } \\
\text { betarthatóságáról. }\end{array}$ \\
\hline $\begin{array}{l}\text { 4. Extrakurrikuláris } \\
\text { tevékenységek: }\end{array}$ & $\begin{array}{l}\text { A tanulók részvétele és részvételi lehetőségei az iskola által } \\
\text { felkínált tanórán kívüli tevékenységekben. }\end{array}$ \\
\hline 5. Az iskola szeretete: & $\begin{array}{l}\text { A tanulók hangulatát, iskolával kapcsolatos lelkesedését és elé- } \\
\text { gedettségét leíró elemek. }\end{array}$ \\
\hline 6. A tanulók hangja: & $\begin{array}{l}\text { A tanulói autonómia támogatottságának megélése azáltal, } \\
\text { hogy a tanulók releváns döntéseket hozhatnak az iskolai min- } \\
\text { dennapokat illetően, illetve úgy érzik, hogy van lehetőségük } \\
\text { véleményük kifejezésére. }\end{array}$ \\
\hline 7. Kortárs kapcsolatok: & $\begin{array}{l}\text { A kortárs, baráti kapcsolatok minőségét feltáró elemek. Ide } \\
\text { sorolhatók a baráti kapcsolatok kiterjedtségét, mennyiségét, az } \\
\text { iskolában megélt magány érzését feltáró elemek. }\end{array}$ \\
\hline 8. Biztonság: & $\begin{array}{l}\text { A tanulók percepciója arról, mennyire érzik magukat bizton- } \\
\text { ságban az iskolai környezetben. }\end{array}$ \\
\hline 9. Tanári támogatás: & $\begin{array}{l}\text { A tanár-diák kapcsolat minőségének megélése, a tanulók per- } \\
\text { cepciója arról, a tanárok mennyire ismerik el teljesítményüket; } \\
\text { elérhetőek-e számukra személyes problémáikkal. }\end{array}$ \\
\hline
\end{tabular}

Az iskolához való viszony megragadására szintén a school connectedness fogalmat alkalmazza Lohmeier és Lee (2012). Hasonlóan Libbey (2004) eredményeihez, Lohmeier és Lee (2012) is megerösítik a fogalom koncepcionális tisztázatlanságát és összefonódását más, hasonló tartalmú fogalmakkal. Értelmezésük az iskolához (és annak különböző szereplőihez) füződő kapcsolatok eltérő minőségei mentén írja le a fogalmat. Az iskolához kötődés megélése szerintük a tanulók percepciója arról, hogy az iskola milyen mértékben gondoskodik róluk (azaz veszi figyelembe egyéni igényeiket), valamint, hogy az egyén mennyire érzi önmagát az iskola tagjának. A koncepció megragadására az összetartozás (connectedness) elméleti megközelítéséből indultak ki. Az összetartozás megélését leíró 
konstruktumot három további elágazás (szubkonstruktum/szint) mentén értelmezték, majd ezt az iskolai kontextusok sajátosságaihoz illesztették (Lohmeier és Lee, 2012).

$\mathrm{Az}$ első szint a valahova tartozás megélése (belongingness), ami tulajdonképpen az egyén percepciója a társas támogatottság általános mértékéről. Karcher és Lee (2002) kiemeli, hogy ez az egyén önértékelésén alapul, melyet a társas támogatottság általános megtapasztalására vonatkoztat. A második szint már a szorosabb, interperszonális kapcsolatok (relatedness) értelmezésére fókuszál, és szintén az egyén szubjektív értékelésén alapul arra vonatkozóan, hogy specifikus, közvetlen személyes kapcsolataiban hogyan éli meg támogatottságát (vö. Karcher és Lee, 2002). Végezetül, a harmadik elem - az összetartozás megélése (connectedness) - az egyén aktív szerepét, involváltságát jelzi társas kapcsolataiban, és azt, ahogyan az általános és interperszonális kapcsolatait fenntartja, értékeli (Karcher és Lee, 2002; Lohmeier és Lee, 2012).

Az előzőekben röviden vázolt három szint alapján Lohmeier és Lee (2012) az iskolához való viszonyulás feltárására egy három komponensü modellt dolgoztak ki, illetve vizsgálták a különböző kapcsolatok lehetséges forrásait is az iskolai kontextusokban. A három feltételezett komponens értelmezését és a kapcsolatok lehetséges forrásait a 3. táblázat összegzi.

3. táblázat. Lohmeier és Lee (2012) három elemü modellje az iskolához tartozás érzésének megragadására (Lohmeier és Lee, 2012. 87. alapján)

\begin{tabular}{|c|c|}
\hline Komponens (Szint) & Tartalmi sajátosságok \\
\hline $\begin{array}{l}\text { Általános } \\
\text { támogatottság } \\
\text { (a valahova tartozás } \\
\text { megélése) } \\
\text { 'Belonging', }\end{array}$ & $\begin{array}{l}\text { - A támogatottság általános percepciója/megélése más tanulók } \\
\text { felől, az iskolában jelen lévő felnőttektől, illetve } \\
\text { - a tanulás és az iskola általános értelmezése (észlelt szerepe az } \\
\text { egyén életében). } \\
\text { - A tanuló érzései arról, hogy mennyire érzi magát az iskola elfo- } \\
\text { gadott tagjának. }\end{array}$ \\
\hline $\begin{array}{l}\text { Specifikus } \\
\text { támogatottság } \\
\text { (szorosabb kötődések } \\
\text { megélésé) } \\
\text { 'Relatedness' }\end{array}$ & $\begin{array}{l}\text { - A társas támogatás kontextus- és kapcsolatspecifikus percepciója. } \\
\text { - A tanuló észlelését ragadja meg arra vonatkozóan, hogy barátai, } \\
\text { osztálytársai és tanárai esetén az adott iskolában miképpen éli } \\
\text { meg kapcsolódását a közösséghez. }\end{array}$ \\
\hline $\begin{array}{l}\text { Elköteleződés } \\
\text { (Összetartozás) } \\
\text { 'Connectedness' }\end{array}$ & $\begin{array}{l}\text { - A tanuló iskolai munkához kapcsolódó erőfeszítéseire, a külön- } \\
\text { böző iskolai tevékenységekbe való bevonódására vonatkozik, } \\
\text { - valamint arra, hogy a tanuló mennyire értékeli iskolai társas kap- } \\
\text { csolatait és az iskolai tevékenységeket. }\end{array}$ \\
\hline A kapcsolatok forrásai & Tartalmi sajátosságok \\
\hline Iskola & $\begin{array}{l}\text { A tanuló viszonyulása az iskolai élet társas kapcsolatokon kívül álló } \\
\text { aspektusaihoz, a tevékenységek, a tanulás fontossága, az iskola szel- } \\
\text { lemiségével való azonosulás. }\end{array}$ \\
\hline $\begin{array}{l}\text { Tanárok/más felnőttek } \\
\text { az iskolában }\end{array}$ & $\begin{array}{l}\text { A tanuló társas kapcsolatai az iskola felnőtt tagjaival: tanárok, segítő } \\
\text { szakemberek, az iskola személyzete. }\end{array}$ \\
\hline Kortársak & $\begin{array}{l}\text { A tanuló társas kapcsolatai kortársaival, beleértve az osztálytársakat, } \\
\text { barátokat. }\end{array}$ \\
\hline
\end{tabular}


Lohmeier és Lee (2012) mérőeszközük (School Connectedness Scale, SCS) megalkotásakor a fenti három szint (lásd 3. táblázat) felhasználásával a tanulók nézeteire és értékeire, valamint az azok alapján bejósolható viselkedésre vonatkozó állításokat dolgoztak ki.

Az elfogadottság és társas támogatás megélésének iskolai kontextusbeli értelmezésére hasonló tartalmú megközelítéssel találkozunk Goodenow és Grady (1993) korábbi kutatásában is. Goodenow és Grady (1993) részben a társas hatások befolyását vizsgálták az akadémiai motiváció, az elköteleződés és az iskolai tevékenységekben való részvétel területein. Az iskolai társas környezet fontos elemeként írták le a tanulók által megélt „,iskolához tartozni” érzést (school belonging). A school belonging fogalma alatt a tanulók észleléseit értették arról, hogy mennyire érzik magukat az iskola részének, azaz élik meg, hogy elfogadottak, támogatottak és tanáraik megbecsülik és tisztelik őket. Elméletüket Goodenow és Grady (1993) Finn (1989) identifikáció-részvétel megközelítésére alapozták. Finn (1989) kutatásai feltárták, hogy annak ellenére, hogy a tanulók (ha csak minimális mértékben is, de) azonosulnak az iskolával, tehát tagként tekintenek önmagukra és úgy vélik, hogy szívesen látják őket az intézményben, társas kapcsolataik hatására mégis eltávolodhatnak annak akadémiai célkitüzéseitől. Ugyanakkor a kutatás arra is rávilágított, hogy az iskolához tartozás megélésében döntő szerepe van a tanulói percepcióknak a tanári támogatás mértékéről (Goodenow és Grady, 1993).

Szintén az iskolához való érzelmi közelség érzését leíró további konstruktum a Jenkins (1997) által használt school bond fogalom. A kifejezés az elköteleződés, a lojalitás és az iskolához tartozás érzését öleli fel, és olyan tényezőkre fókuszál, mint részvétel az iskolai tevékenységekben, azonosulás az iskolai szabályokkal és azok betartása, valamint a tanárok tisztelete. Jenkins (1997) a fogalom értelmezésekor fontos elemnek tartja mind az érzelmi kapcsolatot (kötődés), mind az iskolai közösség felé megmutatkozó viselkedéses megnyilvánulásokat (bevonódás és ráfordítás). Megközelítésében a fogalom négy komponens mentén írható le, melyeket a 4. táblázat összegez.
Az elfogadottság és társas támogatás megélésének iskolai kontextusbeli értelmezésére hasonló tartalmú megközelitéssel találkozunk Goodenow és Grady (1993) korábbi kutatásában is. Goodenow és Grady (1993) részben a társas hatások befolyását vizsgálták az akadémiai motiváció, az elkötelezódés és az iskolai tevékenységekben való részvétel területein. Az iskolai társas környezet fontos elemeként irták le a tanulók. által megélt „iskolához tartozni” érzést (school belonging). A school belonging fogalma alatt a tanulók észleléseit értették arról, hogy mennyire érzik magukat az iskola részének, azaz élik meg, hogy elfogadottak, támogatottak és tanáraik megbecsülik és tisztelik óket. Elméletüket Goodenow és Grady (1993) Finn (1989) identifikáció-részvétel megközelitésére alapozták. 


\begin{tabular}{|c|c|}
\hline \multicolumn{2}{|c|}{$\begin{array}{l}\text { 4. táblázat. Jenkins (1997) négyelemü iskolai attitüd modelljének összetevõi és azok tartalma } \\
\text { (saját szerkesztés) }\end{array}$} \\
\hline Komponens (Szint) & Tartalmi sajátosságok \\
\hline Kötődés: & $\begin{array}{l}\text { melynek során az egyén törődik másokkal, és fontossá válnak } \\
\text { számára mások elvárásai és véleménye. }\end{array}$ \\
\hline Elköteleződés: & mely ebben az esetben az akadémiai célkitüzések értékelését jelenti. \\
\hline Bevonódás: & azaz részvétel az iskolához kapcsolódó tevékenységekben. \\
\hline $\begin{array}{l}\text { Egyéni meggyőződések } \\
\text { (nézetek): }\end{array}$ & arról, hogy az iskolai szabályok igazságosak és betartásuk fontos. \\
\hline
\end{tabular}

Ugyancsak az érzelmi és szociális közelség megélését, az iskolában töltött idő minőségét és az iskolai közösséghez tartozás érzését ragadja meg a school attachment fogalom (Moody és Bearman, 1998, idézi Stern, 2012). Hasonlóan Goodenow és Grady (1993) kutatásának eredményeihez, a kapcsolódó kutatások megerősítették, ennek alakulásában az egyik legfontosabb közvetítő elem a tanár-diák interakció (Gottfredson, 2015).

Az iskolaiattitüd-kutatásokban egyre gyakrabban megjelenő, leginkább a tanulói elköteleződés és bevonódás minőségét, sajátosságait és annak különbözö dimenziót kifejező fogalom az ún. engagement. A konstruktum és lehetséges összetevőinek értelmezése rendkívül széles skálán mozog, abban azonban viszonylag egységes megközelítésekkel találkozhatunk, hogy a fogalom a tanulók különböző motivációs, affektív, kognitív és viselkedéses mintázatait jelöli (vö. Fredricks és mtsai, 2004; Appleton és mtsai, 2008; Eccles és Wang, 2012).

A terminológiai sokszínűség és a csekély konszenzus a fogalom tartalmát illetően ebben az esetben is megnehezíti a pontos definiálást (vö. Fredricks, 2004; Appleton és mtsai, 2008; Griffiths és mtsai, 2009; Eccles és Wang, 2012). Fredricks és munkatársai (2004) úgy fogalmaznak, hogy a bevonódás/elköteleződés iskolai kontextusra vetített lehetősége sok esetben úgy értelmeződik, mint az iskolától való elidegenedés (alienation) ellenszere. A fogalom komplexitása miatt Fredricks és munkatársai (2004) szerint azt meta-konstruktumként érdemes értelmeznünk. Megközelítéseikben Appleton és munkatársai (2008) és Griffiths
A terminológiai sokszinúség és a csekély konszenzus a fogalom tartalmát illetốen ebben az eset-

ben is megneheziti a pontos definiálást (vö. Fredricks, 2004; Appleton és mtsai, 2008; Griffiths és mtsai, 2009; Eccles és Wang, 2012). Fredricks és munkatársai (2004) úgy fogalmaznak, hogy a bevonódás/ elkötelezôdés iskolai kontextusra vetített lehetósége sok esetben úgy értelmezódik, mint az iskolától való elidegenedés (alienation) ellenszere. Afogalom komplexitása miatt Fredricks és munkatársai (2004) szerint azt meta-konstruktum-

ként érdemes értelmeznünk. Megközelitéseikben Appleton és munkatársai (2008) és Griffiths és munkatársai (2009) is kiemelik, hogy egy többdimenziós fogalomról van szó, és az engagement terminus az iskolai élet különbözó területeihez kapcsolódóan a tanulók érzelmeinek, nézeteinek és tevékenységeinek sajátosságait tárja fel. 
és munkatársai (2009) is kiemelik, hogy egy többdimenziós fogalomról van szó, és az engagement terminus az iskolai élet különbözö területeihez kapcsolódóan a tanulók érzelmeinek, nézeteinek és tevékenységeinek sajátosságait tárja fel.

A fogalom koncepcionalizálását az is tovább árnyalja, hogy nincs egységes megközelítés az összetevők számát és tartalmát illetően (vö. Appleton és mtsai, 2008; Griffiths és mtsai, 2009; Eccles és Wang, 2012; Alrashidi és mtsai, 2016). A korai megközelítések (vö. Appleton és mtsai, 2008; Alrashidi és mtsai, 2016) két komponens mentén írták le a fogalmat, melyek a 1. magatartásra vonatkozó, illetve a tanulók érzelmi válaszait megragadó, 2. affektív komponensek voltak, majd a három komponensü modellek esetén ez kibővült egy kognitív komponenssel is. Az egyes komponensek tartalmát részletesen az 5. táblázat összegzi.

5. táblázat. Az elkötelezödés/bevonódás három komponensü modellje (Appleton és mtsai, 2008; Griffiths és mtsai, 2009; Eccles és Wang, 2012 alapján, saját szerkesztés)

\begin{tabular}{|c|c|}
\hline Komponens & Tartalmi sajátosságok \\
\hline $\begin{array}{l}\text { Viselkedéses } \\
\text { komponens }\end{array}$ & $\begin{array}{l}\text { A magatartásra/viselkedésre vonatkozó elem a következő területekre fóku- } \\
\text { szált: } \\
\text { - az iskolai szabályok és normák interiorizálása; } \\
\text { - az iskolai munkát zavaró viselkedés elutasítása; } \\
\text { - részvétel a tanuláshoz kapcsolódó iskolai tevékenységekben (például } \\
\text { bekapcsolódás a tanórai beszélgetésekbe, kérdések megfogalmazása, } \\
\text { figyelem, koncentráció és erőfeszítés a tanulás érdekében); illetve } \\
\text { - részvétel a különbözö iskolai tevékenységekben (például bekapcsoló- } \\
\text { dás a tanórán kívüli programokba, tisztségek vállalása az iskola életé- } \\
\text { ben). }\end{array}$ \\
\hline $\begin{array}{c}\text { Affektív } \\
\text { komponens }\end{array}$ & $\begin{array}{l}\text { A két komponensủ modell affektív összetevője a tanulók iskolához és tanu- } \\
\text { láshoz kapcsolódó érzelmi sajátosságait vizsgálta, úgymint: } \\
\text { - az érdeklődés; } \\
\text { - azonosulás, kötődés, a társakhoz és a tanárokhoz füződő érzelmi kap- } \\
\text { csolatok jellege (pozitív/negatív) és minősége; valamint } \\
\text { - a tanuláshoz kapcsolódó egyéb attitüdök jellemzői és } \\
\text { - a tanulók általános érzelmi állapota az iskolában (szorongás, boldog- } \\
\text { ság, közöny, unalom). }\end{array}$ \\
\hline $\begin{array}{c}\text { Kognitív } \\
\text { komponens }\end{array}$ & $\begin{array}{l}\text { Akésőbbi kutatások már a három elemü modell mellettérveltek (Frederickson } \\
\text { és mtsai, 2004), és az affektív és viselkedéses összetevők mellett már egy } \\
\text { kognitív komponens beépítését is javasolták, ami: } \\
\text { - az önszabályozás, } \\
\text { - a tanulási célok és stratégiák és } \\
\text { - a tanulói ráfordítás mértékét ragadta meg. }\end{array}$ \\
\hline
\end{tabular}

A három komponensü modell mellett számos kutatás (Appleton és mtsai, 2008; Griffiths és mtsai, 2009; Reschly és Christenson, 2012) négy komponens alkalmazását javasolja. A viselkedéses és affektív elemek mellett a további két elágazást a kognitív és akadémiai komponensek jelölik. A négy komponensü modell esetén a kognitív komponens a tanulás értékelésére, az önszabályozás és személyes tanulási célok egyéni jellemzőire épül, míg az akadémiai komponens olyan elemekre vonatkozik, mint az osztálytermi tanulási helyzetekkel, a házi feladat elkészítésével és egyéb tanulmányi tevékenységekkel töltött idő.

Willms (2003) a PISA vizsgálatokban alkalmazott értelmezés kapcsán az elköteleződés/ bevonódás kognitív és affektív komponenseit emeli ki. Megközelítésében az engagement annak kifejezése, hogy a tanulók mennyire értékelik a tanulást és tanulási eredményeket, 
illetve vesznek részt az iskolai tevékenységekben. Az elköteleződés/bevonódás tehát a tanulás, az iskolai tevékenységek és az iskola mint társadalmi intézmény iránti diszpozíciókat takarja.

$\mathrm{Az}$ egyes komponensek értelmezése kapcsán Fredricks és munkatársai (2004) kiemelik, hogy fontos az egyes részterületek áttekintése, mely így a tanulók iskolai viszonyulásának gazdagabb megértését segíti, és ezáltal területspecifikus megismerést tesz lehetővé, azonban arra is felhívja figyelmet, hogy a valóságban ezek a területek nem különülnek el ennyire élesen egymástól, hanem dinamikusan összekapcsolódó komponensekről van szó.

Schaufeli és munkatársai (2002) egy másik aspektus felöl közelítettek az engagement felé. A fogalom koncepcionalizálása során annak munkahelyi, szervezeti keretek közötti alkalmazását vették alapul, és vizsgálták a kiégés-elköteleződés (mint gyakran egymás ellenpólusainak tekintett fogalmak) tanulási helyzetekre adaptálhatóságát. $\mathrm{Az}$ iskolai kontextusokat elemezve amellett érveltek, hogy a munkavállalói elköteleződés valójában párhuzamba állítható az iskolai munka jellegzetességeivel is. Hasonlóan, a tanulók is strukturált környezetben, egy meghatározott cél elérése érdekében, rögzített időkeretben és munkaformákban tevékenykednek, így a munkahelyi és iskolai kontextusok számos tekintetben egyezők. Kutatásukban felsőoktatási hallgatók vettek részt, eredményeik azonban tovább árnyalhatják a fogalom értelmezését.

Elköteleződés-modelljükben Shaufeli és munkatársai (2002) három dimenziót azonosítottak, és elméletüket elsősorban a megismerési és tanulási folyamat minőségére építő megközelítésekhez kapcsolhatjuk. Az elköteleződés/bevonódás értelmezésükben egy, az egyén számára kielégítő, pozitív, tanulási Az elkötelezôdés három leírt dimenziója: 1. energia, 2. elkötelezôdés és 3. elmélyültség. Az energia dimenzió fó jellemzói a rugalmas mentális beállitódás, motiváció a szükséges erófeszitések megtételére és az egyén kitartása. Az elkötelezódés a lelkesedés, inspiráció és a kihivás megélését fogja át, és az egyén erós involváltságát feltéte-

lezi. Végezetül, a harmadik dimenzió az elmélyültség, mely jellemzóje a tevékenység során megmutatkozó erós koncentráció, az idó érzékelésének megváltozása: az egyén nehezen szakad el az adott tevékenységtôl, és úgy érzékeli, rövid idót töltött el vele. Schaufeli és munkatársai (2002) modellje - ahogy erre maguk is utalnak - szorosan kapcsolódik a flow-élményhez. Shernoff és Csíkszentmihályi (2009) a flow-élmény iskolai megélése kapcsán hasonló jellegzetességeket írnak le: intenzív koncentráció, elmélyülés, az idóérzék. elmosódása, mentális és fizikai eróforrások megeróltetés nélküli mozgósítása. tevékenységhez kapcsolódó állapot. Jellemzője, hogy nem egy adott pillanathoz vagy kontextushoz kapcsolódik, és nem kifejezetten egy attitüdtárgyra vagy viselkedésre vonatkoztatható, hanem egy folytonosan fennálló kognitív-affektív állapot.

Az elköteleződés három leírt dimenziója: 1. energia, 2. elköteleződés és 3. elmélyültség. Az energia dimenzió fő jellemzői a rugalmas mentális beállítódás, motiváció a szükséges erőfeszítések megtételére és az egyén kitartása. Az elköteleződés a lelkesedés, inspiráció és a kihívás megélését fogja át, és az egyén erős involváltságát feltételezi. 
Végezetül, a harmadik dimenzió az elmélyültség, mely jellemzője a tevékenység során megmutatkozó erős koncentráció, az idő érzékelésének megváltozása: az egyén nehezen szakad el az adott tevékenységtől, és úgy érzékeli, rövid időt töltött el vele. Schaufeli és munkatársai (2002) modellje - ahogy erre maguk is utalnak - szorosan kapcsolódik a flow-élményhez. Shernoff és Csíkszentmihályi (2009) a flow-élmény iskolai megélése kapcsán hasonló jellegzetességeket írnak le: intenzív koncentráció, elmélyülés, az időérzék elmosódása, mentális és fizikai erőforrások megerőltetés nélküli mozgósítása. Schaufeli és munkatársai (2002) maguk is jelzik, hogy modelljük flow-szerü élményt ír le, azonban úgy vélik, hogy míg az egy rövidebb ideig tartó, örömteli állapot átélése, addig az elköteleződés tartósabb, folytonosan jelen lévő kognitív-affektív beállítódás (vö. Shernoff és Csíkszentmihályi, 2009; Schaufeli és mtsai, 2001).

Szintén az iskolai élet minőségét ragadja meg az iskolai jóllét koncepciója (school well-being). Konu és Rimpela (2002) Allardt (1989) szociológiai megközelítésű jóllét-modelljére építve dolgozták ki az iskolai jóllét koncepcióját. Allardt elméletében az életminőséget és az azzal való elégedettséget is meghatározó szükségleteket három kategóriába sorolta: egyrészt a materiális feltételeket leíró ún. having, másrészt a társas kapcsolatok minőségét kifejező ún. loving, harmadrészt pedig az önmegvalósítást megragadó ún. being kategóriákba. Mindhárom kategória esetén beszélhetünk objektív és szubjektív indikátorokról, melyek kifejezhetik a jóllét megélését. Allardt modelljét alapul véve, Konu és Rimpela (2002) az iskolai környezet sajátosságaihoz illesztették a jóllét-modellt. Koncepciójukban az oktatás-nevelés, a tanulás és az ehhez kapcsolódó eredmények, valamint a jóllét szorosan összekapcsolódik, és az iskolai jóllét négy dimenzió köré épül, melyek Allardt fentiekben vázolt jóllét-kategóriáit veszik alapul (6. táblázat).

6. táblázat: Az iskolai jóllét modellje Konu és Rimpela (2002) alapján, saját szerkesztés

\begin{tabular}{|c|l|}
\hline Dimenzió & \multicolumn{1}{c|}{ Tartalom } \\
\hline Iskolai feltételek: & $\begin{array}{l}\text { Konu és Rimpela (2002) ide sorolja az iskola fizikai környezetét, az } \\
\text { iskolában nyújtott szolgáltatásokat (például étkezés), illetve az olyan } \\
\text { szervezési sajátosságokat, mint csoportlétszám, órarend, valamint a } \\
\text { biztonságos légkört. }\end{array}$ \\
\hline 'having' & $\begin{array}{l}\text { a dimenzió a tanulási környezet szociális sajátosságait írja le. Ide sorol- } \\
\text { hatók az iskolai klíma, a csoportdinamika jellegzetességei, a tanár-diák } \\
\text { interakciók, a kortárs kapcsolatok, valamint a szülökkel való kapcso- } \\
\text { lattartás minősége. }\end{array}$ \\
\hline 'loving' & $\begin{array}{l}\text { ez alatt Konu és Rimpela (2002) mindazokat a lehetöségeket értette, } \\
\text { melyeket az iskola megteremt a tanulók önkifejezésének, önmagvaló- } \\
\text { sításának támogatására, így: a tanulók munkájának értékelése és tiszte- } \\
\text { lete, az önbecsülés erösítése, a kreativitás és az önkifejezés támogatása. }\end{array}$ \\
\hline 'being' & $\begin{array}{l}\text { A negyedik dimenzió Konu és Rimpela (2002) megközelítésében az án } \\
\text { egészségi állapotot megragadó kategória, mely a tanulók mentális és } \\
\text { fizikai állapotát méri fel (pszichoszomatikus tünetek megjelenése, kró- } \\
\text { nikus betegségek). }\end{array}$ \\
\hline Egészség:
\end{tabular}

Alanen, Konu és Rimpela (2002) egy későbbi kutatásukban megerősítő faktorelemzéssel vizsgálták az általuk kidolgozott jóllét-modell illeszkedését. Eredményeik a koncepció jó alkalmazhatóságát jelezték.

Az iskolai jóllét fogalmához köthető Baker és Maupin (2009) kutatása is. Az iskolai jóllét megélését az iskolai elégedettség (school satisfaction) fogalommal fejezik ki, mely 
a tanulók szubjektív, kognitív ítélete az iskolai élet minőségéről. A szubjektív jóllét értelmezésükben három komponensü: pozitív érzelmek, negatív érzelmek és az egyén elégedettsége.

\section{Az iskolához való viszonyt meghatározó további tényezők}

Láthattuk, hogy az iskolai attitűd komplex, széttartó, az iskolai élet számos aspektusát felölelő fogalom. Megragadhatóságának és kutatásának további nehézsége azonban, hogy nehezen elválasztható más, az iskolai tevékenységekhez direkt vagy indirekt módon kapcsolódó faktoroktól, és nem kiragadható az egyént körülvevő társas-társadalmi kontextusból.

Ennek összetettségét - az iskolai attitűd alakulása esetén is - jól mutatják például a humánökológiai modellek megközelítései.

$\mathrm{Az}$ egyén fejlődésére ható tényezőket egymásra épülő rétegek rendszereként leíró humánökológiai modell (vö. Bronfenbrenner, 1979) az egyén pszichológiai fejlődését közvetlenül meghatározó elemeknek a mikrorendszer tényezőit tekinti. Az iskolai attitűdöt meghatározó változók közül ilyen tényezők lehetnek a családi környezet jellemzői (Baker és Maupin, 2009, Stern, 2012). A tanuló szocio-ökonómiai státusza, a szülők iskolázottsága és nézetrendszere közvetlen hatással van a gyermek akadémiai teljesítményére és jövőbeni céljaira (Stern, 2012; Moorman és Pomernatz, 2010). Egy magasan iskolázott, kedvező jövedelemmel rendelkező szülő látható szerepmodell lehet gyermeke életében, ami azt közvetítheti, hogy a tanulmányi siker valójában a későbbi, jól-fizető, magas presztízsű pozíciók betöltéséhez járul majd hozzá (Stern, 2012). Hasonlóan a szülői hatások szerepét erősíti Moorman és Pomerantz (2010) kutatása. A kutatás az anyák tanulásban nyújtott támogatásának minőségét és típusait vizsgálta. Eredményeik rámutattak, hogy az, ahogyan az anyák saját nézetrendszerükben gondolkodnak a tanulásról, meghatározza bevonódásukat gyermekeik tanulásába. Azok az édesanyák, akik úgy vélték, hogy a gyermek képességei nem formálhatók, sokkal kritikusabbak voltak, a támogatás során a gyermek eredményeire fókuszáltak, és kevésbé segítették gyermekeiket a tanulásban való elakadás során. Azok az édesanyák, akik úgy vélték, hogy a gyermek képességei alakíthatók, konstruktív, valódi választási lehetőségeken alapuló tanulási helyzeteket

A tanuló szocio-ökonómiai státusza, a szülók iskolázottsága és nézetrendszere közvetlen hatással van a gyermek akadémiai teljesítményére és jövóbeni céljaira (Stern, 2012; Moorman és Pomernatz, 2010). Egy magasan iskolázott, kedvezó jövede-

lemmel rendelkezó szüló látható szerepmodell lehet gyermeke életében, ami azt közvetitheti, hogy a tanulmányi siker valójában a késóbbi, jól-fizetó, magas presztizsú poziciók betöltéséhez járul majd hozzá

(Stern, 2012). Hasonlóan a szülői hatások szerepét erósíti Moorman és Pomerantz (2010) kutatása. A kutatás az anyák. tanulásban nyújtott támogatásának minóségét és típusait vizsgálta. Eredményeik rámutattak, hogy az, ahogyan az anyák saját nézetrendszerükben gondolkodnak a tanulásról, meghatározza bevonódásukat gyermekeik tanulásába. 
biztosítottak gyermekeiknek, és több pozitív megerősítést adtak. Tehát az anyák tanulásról és képességekről alkotott nézetei meghatározták, hogy milyen tanulási élményt biztosítanak gyermekeiknek, ami később hatással lehet a gyermekek tanulási helyzetekbe való bevonódására és motivációira (Moorman és Pomerantz, 2010).

A szülői befolyás mellett, az iskolához való viszonyulás alakulását olyan intraperszonális tényezők is alakítják, mint (a teljesség igénye nélkül) az énkép vagy énhatékonyság érzése. Az énhatékonyság érzésének kialakulásában szerepet játszanak az egyén közvetlen tapasztalásai, a környezettől kapott visszajelzések és szubjektív észlelései a sikeres vagy kevésbé sikeres tevékenységeit illetően. Az iskolai attitüd és az énhatékonyság szorosan összefügg, hiszen a múltbeli tapasztalatok (siker/kudarc) befolyásolják majd az egyén meggyőződését arról, hogy a jövőbeni tapasztalatok is összhangban állnak majd ezekkel a tapasztalatokkal: minél erősebb az egyén énhatékonyság-érzése, annál magasabb célokat állít fel önmaga számára. Hosszú távon a pozitív érzelmek szélesítik az egyén kognitív és viselkedéses repertoárját, ami hozzájárul a kognitív megküzdési (coping) stratégiák bővítéséhez, ez pedig növelheti az elköteleződést, adaptációt és bevonódást eredményez a jövőbeni tanulási helyzetekbe (Stern, 2012).

A családi környezet és a pszichológiai jellemzők mellett azonban további tényezők is hatással lehetnek a tanulók iskolai attitüdjeire. Ilyen meghatározó elem lehet a kortárs kapcsolatok minősége, az iskolai közösségben felmerülö konfliktusok és a csoportdinamika egyéb jellemzői (pl. klikkesedés) (Stern, 2012; Baker és Maupin, 2009), valamint az iskolai szervezet olyan sajátosságai, mint a szervezeti klíma, az iskolát körülvevő tágabb társadalmi kontextus.

\section{Összegzés, a kutatás további lehetőségei}

Az előzőekben az iskolai attitüd ernyője alá sorolható fogalmak koncepcionális elemzésével foglalkoztunk. Az iskolai attitüd fogalmát ernyőfogalomnak tekintettük, ami széttartó és komplex természetü.

Látható volt, hogy a fogalmi sokszínűség megnehezíti az egyes konstruktumok pontos definiálását, ugyanakkor magukban rejtik az iskolai attitüd átfogó értelmezési lehetőségét is, kiszélesítve annak fókuszát. Az eltérő fogalmak az iskolai élet különböző területeire fókuszálnak, ugyanakkor számos tartalmi átfedést is mutatnak.

Libbey (2004) a kapcsolódó fogalmak rendszerezésére és elemzésére irányuló kutatása megerősítette azokat a változókat, melyek az iskolaiattitüd-kutatások permanens elemei, ezek a következők voltak: akadémiai elköteleződés; az iskolához tartozás érzése; tanulói percepciók az iskolai fegyelemről és igazságosságról; extrakurrikuláris tevékenységek; az iskola szeretete; a tanulók hangja; kortárs kapcsolatok; biztonság és tanári támogatás.

Az iskolai attitűdöt az iskolához való érzelmi-társas közelség, a kötődés érzésén keresztül megragadó konstruktumok (Lohmeier és Lee, 2012; Goodenow és Grady, 1993; Jenkins, 1997) a társas kapcsolatok minőségét, a kapcsolatok értékelését, az azokba való bevonódás és ráfordítás mértékét, valamint a társaktól és tanároktól megtapasztalt elfogadás és támogatás érzését állították a középpontba.

Az elköteleződés/bevonódás mint meta-konstruktum a tanulók affektív, kognitív és viselkedéses mintázatait jelölte. A tartalmi diverzitás ebben az esetben is megfigyelhető volt elsősorban az összetevők számát és tartalmát illetően (vö. Willms, 2003; Fredricks és mtsai, 2004; Appleton és mtsai, 2008; Griffiths és mtsai, 2009; Eccles és Wang, 2012; Reschly és Christenson, 2012). Látható volt azonban az is, hogy az elköteleződés/bevonódás több komponensű modelljei olyan átfogó konstruktumok lehetnek, melyek komplex képet adhatnak a tanulók iskolához füződő kapcsolatáról és annak elágazásairól. 
Hasonlóan többszempontú értelmezést kínált az iskolai élet minőségére az iskolai jóllét modellje is, amely Konu és Rimpela (2002) értelmezésében alkalmas lehet az iskolák értékelésére is az adott kategóriák mentén.

Az iskolai attitüd koncepcionális megalapozottságának és ezek alapján kutatásának jelentősége, hogy az iskola iránti viszonyulások meghatározzák a tanulói motivációt, befolyásolják a társas kapcsolatok minőségét, az egyén szubjektív jóllétét, ezeken keresztül pedig hatással vannak az énhatékonyság érzésére, az egyén motivációjára és iskolai teljesítményére is.

Mindezek alapján a jelen tanulmány keretében bemutatott elméleti kutatás - a fogalom komplexitásának feltárása mellett - megalapozta egy mérőeszköz kialakítását és egy empirikus vizsgálat keretében annak kipróbálását.

\section{Támogatás}

A tanulmány elkészítése során a szerző a Nemzet Fiatal Tehetségeiért Ösztöndíjban (NTP-NFTÖ-18-B) részesült.

\section{Irodalom}

Alrashidi, O., Phan, H. \& Ngu, B. H. (2016). Academic Engagement: An Overview of Its Definitions, Dimensions, and Major Conceptualisations. International Education Studies, 9(12), 41-52. DOI: 10.5539/ies.v9n12p41

Appleton, J., Christenson, S. L. \& Furlong, M. (2008). Student engagement with school: Critical conceptual and methodological issues of the construct. Psychology in the Schools, 45, 369-386. DOI: 10.1002/pits.20303

Baker, J. A. \& Maupin, A. N. (2009). School Satisfaction and Children's Positive School Adjustment. In Gilman, R., Huebner, E. S. \& Furlong, M. J. (szerk.), Handbook of Positive Psychology in Schools. New York - London: Routledge. 189-196.

Corsaro, W. A. (2015). The Sociology of Childhood. Indiana University, Bloomington: SAGE Publications. DOI: $10.4135 / 9781483399027$

Csapó Benő (2000). A tantárgyakkal kapcsolatos attitűdök összefüggései. Magyar Pedagógia, 100(3), 343-366.

Csapó Benő (2002a). Az iskolai tudás. Budapest: Osiris Kiadó.

Csapó Benő (2002b). A tudáskoncepció változása: nemzetközi tendenciák és a hazai helyzet. Új Pedagógiai Szemle, 52(2), 38-45.

Czető Krisztina (2018). Fiatalok iskolaképének, iskolával kapcsolatos nézeteinek, jövőképének vizsgálata. Nem publikált PhD. értekezés.

Eccles, J. \& Wang, T. M. (2012). So What is Student Engagement Anyway? In Reschly, A. L. \& Christenson, S. L. (szerk.), Handbook of Research on Student
Engagement. London: Springer. 133-146. DOI: 10.1007/978-1-4614-2018-7_6

Fiske, S. T. (2006). Társas alapmotívumok. Budapest: Osiris Kiadó.

Fredricks, J. A., Blumenfeld, P. C. \& Paris, A. H. (2004). School Engagement: Potential of the Concept, State of the Evidence. Review of Educational Research, 74(1), 59-109. DOI: 10.3102/00346543074001059

Freeman, M. (1998). The Sociology of Childhood and Children's Rights. The International Journal of Children's Rights, 6(4), 433-444. DOI: 10.1163/15718189820494175

Freeman, M. (2000). The Future of Children's Rights. Children and Society, 14, 277-293. DOI: 10.1111/ j.1099-0860.2000.tb00183.x

Freeman, M. (2009). Children's Rights as Human Rights: Reading the UNCRC. In Qvortrup, J., Corsaro, W. A. \& Honig, M. S. (szerk.), The Palgrave Handbook of Childhood Studies. New York: Palgrave Macmillan. 377-394.

Gazsó Ferenc \& Laki László (2004). Fiatalok az újkapitalizmusban. Budapest: Napvilág Kiadó.

Gillis, J. (2009). Transitions to modernity. In Qvortrup, J., Corsaro, W. A. \& Honig, M. S. (szerk.), The Palgrave Handbook of Childhood Studies. New York: Palgrave Macmillan. 114-127.

Golnhofer Erzsébet \& Szabolcs Éva (2005). Gyermekkor: nézöpontok, narrativák. Budapest: Eötvös József Könyvkiadó.

Goodenow, C. \& Grady, K. E. (1993). The relationship of school belonging and friends' values 
to academic motivation among urban adolescent students. Journal of Experimental Education, 62(1), 60-71. DOI: 10.1080/00220973.1993.9943831

Gottfredson, D. C., Marciniak, E. M., Birdseye, A. T. \& Gottfredson, G. D. (2010). Increasing Teacher Expectations for Student Achievement. The Journal of Educational Research, 88(3), 155-163. DOI: 10.1080/00220671.1995.9941294

Griffiths, A. J., Sharkey, J. D. \& Furlong, M. J. (2009). Student Engagement and Positive School Adaptation. In Gilman, R., Huebner, E. S. \& Furlong, M. J. (szerk.). Handbook of Positive Psychology in Schools. New York - London, Routledge. 197-212.

Hendrick, H. (1997). Construction and reconstructions of British childhood: an interpretive survey, 1800 to the present. In James, A. \& Prout, A. (szerk.), Constructing and Reconstructing Childhood. London: Taylor \& Francis Group. 33-61.

Hunyady Györgyné \& M. Nádasi Mária (2014). Az iskolakép változatai és változásai. Budapest: ELTE Eötvös Kiadó.

James, A. (2013). Socialising Children. London, Palgrave Macmillan. DOI: 10.1057/9781137317339

Jenkins, P. H. (1997). School Delinquency and the School Social Bond. Journal of Research in Crime and Delinquency, 34(3), 334-367. DOI: $10.1177 / 0022427897034003003$

Karcher, M. J. \& Lee, Y. (2002). Connectedness among taiwanese middle school students: a validation study of the hemingway measure of adolescent connectedness. Asia Pacific Education Review, 3, 1. 92-114. DOI: 10.1007/bf03024924

Kjørholt, A. (2008). Children as New Citizens: In the Best Interests of the Child? In James, A. \& James, A. L. (szerk.). European Childhoods. Cultures, Politics and Childhoods in Europe. New York: Palgrave Macmillan. 14-37. DOI: 10.1057/9780230582095_2

Lansdown, G. (2003). Children's Rights. In Mayall, B. (szerk.), Children's Childhoods: Observed and Experienced. London: The Falmer Press. 33-45.

Libbey, H. P. (2004). Measuring Student Relationships to School: Attachment, Bonding, Connectedness, and Engagement. Journal of School Health, 74(7), 274-283. DOI: 10.1111/j.1746-1561.2004. tb08284.x

Lohmeier, J. \& Lee, S. (2011). A school connectedness scale for use with adolescents. Educational Research and Evaluation, 17, 85-95. DOI: 10.1080/13803611.2011.597108

Lundy, L. (2005). Family Values in the Classroom? Reconciling Parental Wishes and Children's Rights in State Schools. International Journal of Law, Policy and the Family, 19(3), 346-372. DOI: 10.1093/ lawfam/ebi027
Mccoach, D. B. \& Siegle, D. (2003). The School Attitude Assessment Survey-Revised: A New Instrument to Identify Academically Able Students Who Underachieve. Educational and Psychological Measurement, 63, 414-429. DOI: 10.1177/0013164403063003005

Monk, D. (2009). Childhood and the law. In Kehily, M. J. (szerk.). An Introduction to Childhood Studies. England: Open University Press.

Moorman, E. A. \& Pomerantz, E. M. (2010). Ability mindsets influence the quality of mothers' involvement in children's learning: An experimental investigation. Developmental Psychology, 46(5), 1354-1362. DOI: 10.1037/a0020376

Nagy Ádám \& Trencsényi László (2012): Szocializációs közegek a változó társadalomban: a nevelés esélyei: család, iskola, szabadidő, media. ISZT Alapítvány.

Quennerstedt, A. (2011). The Construction of Children's Rights in Education - a Research Synthesis. The International Journal of Children's Rights, 19, 661-678. DOI: 10.1163/157181811x570708

Rapos Nóra (2003). Az iskolai félelmek vizsgálata. Iskolakultúra, 13(5), 107-112.

Reschly, A. L. \& Christenson, S. L. (2012). Jingle, jangle and conceptual haziness: Evolution and future directions of the engagement construct. In Reschly, A. L. \& Christenson, S. L. (szerk.), Handbook of Research on Student Engagement. London: Springer. 3-19. DOI: 10.1007/978-1-4614-2018-7 1

Réthy Endréné (2009). Tanulói vélekedések az iskoláról. Az iskola mint örömforrás? In Szabolcs Éva (szerk.), Ifjúkorok, gyermekvilágok. Budapest: Eötvös József Könyvkiadó. 11-45.

Schaufeli, W. B., Salanova, M., González-romá, V. \& Bakker, A. B. (2002). The Measurement of Engagement and Burnout: A Two Sample Confirmatory Factor Analytic Approach. Journal of Happiness Studies, 3(1). 71-92. DOI: 10.1023/a:1015630930326

Shernoff, D. J. \& Csíkszentmihályi, M. (2009). Flow in schools. In Gilman, R., Huebner, E. S. \& Furlong, M. J. (szerk.), Handbook of Positive Psychology in Schools. New York - London: Routledge. 131-145.

Smith E. R., Mackie D. M. \& Claypool H. M. (2017). Attitűdök és attitűdváltozás. In Smith, E. R., Mackie, D. M. \& Claypool, H. M. (szerk.). Szociálpszichológia. Budapest: ELTE Eötvös Kiadó.

Stern, M. (2012). Evaluating and Promoting Positive School Attitude in Adolescents. SpringerBriefs in School Psychology. DOI: 10.1007/978-1-4614-3427-6

Szabó Éva \& Virányi Barbara (2015). Az iskolai kötődés jelentősége és vizsgálata. Magyar Pedagógia, 111(2), 111-125.

Szabó Éva, Zsadányi Zsuzsa \& Szabó Hangya Lilla (2015). Ki szeret iskolába járni? Az iskolai kötődés, a motiváció, az énhatékonyság és a tanulmányifelelősség-vállalás vizsgálata. Iskolakultúra, 25(10), 5-20. DOI: 10.17543/iskkult.2015.10.5 
Szabolcs Éva (2011). Gyermekböl tanuló. Az iskolás gyermek, 1868-1906. Budapest: Gondolat Kiadó.

Tisdall, E., Kay, M \& Punch, S. (2012). Not so 'new'? Looking critically at childhood studies. Children's Geographies, 3(10), 249-264. DOI: 10.1080/14733285.2012.693376

Willms, J. D. (2003). Student engagement at school. A sense of belonging and participation. Results from PISA 2000. OECD. DOI: 10.1787/9789264018938-en
Zeiher, H. (2009). Institutialization as a Secular Trend. In Qvortrup, J., Corsaro, W. A. \& Honig, M.-S. (szerk.), The Palgrave Handbook of Childhood Studies. New York: Palgrave Macmillan. 127-140.

Zinnecker, J. (2001). Children in Young and Aging Societies. The order of generations and models of childhood in comparative perspectives. In Hofferth, S. \& Owens, T. J. (szerk.). Children at the Millenium: Where we have come from, where are we going? Netherlands: Elsevier Sience Ltd.

\begin{abstract}
Absztrakt
A tanulók iskolához való viszonyulásainak, az iskolai életben való részvételük minőségének megragadására a nemzetközi szakirodalomban különböző elméleti konstrukciókkal találkozhatunk (vö. Libbey, 2004; Stern, 2012). Ezek az iskola iránti attitüdöket különböző fogalmakkal írják le, és a koncepcionális tisztázatlanság, a fogalmi átfedések megnehezítik a jelenség kutatását is (Libbey, 2004). A széttartó megközelítések az iskolai élet különböző területeire fókuszálnak, ugyanakkor számos tartalmi egyezést is mutatnak. Jelen elméleti kutatás a tanulók iskolához kapcsolódó kognitív, affektív és viselkedéses viszonyulásait, azok mintázatait, valamint az iskolai mindennapokban való részvételük minőségét megragadó konstruktumok összehasonlító-elemző vizsgálatával foglalkozik. Az iskolai attitűdöt az iskolához való érzelmi-társas közelség érzésén keresztül megragadó konstruktumok (school connectedness/belonging/bond) a társas kapcsolatok minőségét, az azokba való bevonódás és ráfordítás mértékét, valamint a társaktól és tanároktól megtapasztalt elfogadás, támogatás érzését állítják a középpontba (vö. Lohmeier és Lee, 2012; Goodenow és Grady, 1993; Jenkins, 1997). Az elköteleződés/bevonódás (engagement) mint meta-konstruktum pedig a tanulók affektív, kognitív és viselkedéses mintázatait jelöli, és itt is megfigyelhető egyfajta tartalmi diverzitás az összetevők számát és tartalmát illetően a különböző megközelítésekben (vö. Fredricks és mtsai, 2004; Appleton és mtsai, 2008; Griffiths és mtsai, 2009; Reschly és Christenson, 2012). Az elköteleződés/bevonódás több komponensű modelljei komplex képet adhatnak a tanulók iskolához füződő kapcsolatáról és annak dimenzióiról. Az iskolai attitüd koncepcionális rendszerező vizsgálata, és ezek alapján kutatásának jelentősége, hogy az iskola iránti viszonyulások meghatározzák a tanulói motivációt, befolyásolják a társas kapcsolatok minőségét, az egyén szubjektív jóllétét, ezeken keresztül pedig hatással vannak az énhatékonyság érzésére és az iskolai teljesítményre is.
\end{abstract}

